\title{
High levels of docosahexaenoic acid are present in eight New World silversides (Pisces: Atherinopsidae)
}

Correspondence:

Jorge Fonseca-Madrigal jfonseca@umich.mx

Submitted October 1, 2019

Accepted March 31, 2020

by Bernardo Baldisserotto

Epub Jun 12, 2020

Online version ISSN 1982-0224

Print version ISSN 1679-6225

Neotrop. Ichthyol

vol. 18, no. 2, Maringá 2020
Docosahexaenoic acid (DHA) is the most critical and least available omega-3 fatty acid in the Western human diet. Currently, the source of omega-3 long chain polyunsaturated fatty acids (LC-PUFA) is mainly dependent on wild fisheries, making this resource unsustainable in the foreseeable future. In recent years, a high rate of biosynthesis and accumulation of DHA has been discovered in a freshwater species (Chirostoma estor) belonging to the Atherinopsidae family. Interest in evaluating fatty acid composition in other members of the family has emerged, so this study compiles original data of flesh composition of eight atherinopsid species from freshwater and brackish environments, either wild or cultured. High levels of DHA (16 to 31\%) were found in all analyzed members of the family, except in C. grandocule, independently of their habitat or origin. The analyzed species of the Jordani group (C.estor, C. promelas and C. humboldtianum) showed high DHA and low EPA levels $(<0.5 \%)$ as previously reported for cultured C. estor. The low trophic niche of these atherinopsids and their fatty acid accumulation capabilities are factors that make these species noteworthy candidates for sustainable aquaculture.

Keywords: Atherinopsid fish, Chirostoma, Menidia, Odontesthes, Omega-3.

1 Instituto de Investigaciones Agropecuarias y Forestales, Universidad Michoacana de San Nicolás de Hidalgo, Morelia, Michoacán, 58337, México. (CAMP) cpalacios@umich.mx; (SCS) entropia109@gmail.com; (EMTC) elva.toledo@umich.mx; (MGRD) grios@umich.mx; (CCMC) cmartinez@umich.mx; (JFM) jfonseca@umich.mx (corresponding author).

2 Consejo Nacional de Ciencia y Tecnología, Instituto de Investigaciones Agropecuarias y Forestales, Universidad Michoacana de San Nicolás de Hidalgo, Morelia, Michoacán, 58337, México. (PNR) pnavarretera@conacyt.mx; (LR) lraggi@conacyt.mx.

3 Graduate School of Marine Science and Technology, Tokyo University of Marine Science and Technology, Tokyo, Japan. carlos@kaiyodai.ac.jp.

4 Centro de Ecología Aplicada del Neuquén, PO Box 7, Junín de los Andes (8371), Neuquén, Argentina. (JPH) pablohualde@yahoo.com.ar; (MAD) mariecheli@yahoo.com.ar. 
O ácido docosahexaenóico (DHA) é o ácido graxo ômega-3 mais importante e menos disponível na dieta humana ocidental. Atualmente, a fonte de ácidos graxos poliinsaturados de cadeia longa ômega-3 (LC-PUFA) depende principalmente da pesca extrativista, tornando esse recurso insustentável em um futuro próximo. Nos últimos anos, uma alta taxa de biossíntese e acúmulo de DHA foi descoberta em uma espécie de água doce (Chirostoma estor) pertencente à família Atherinopsidae. Deste modo, surgiu o interesse em avaliar a composição de ácidos graxos em outros membros da família. Portanto, este estudo compila dados originais da composição de carne de oito espécies de aterinopsídeos de ambientes de água doce e salobra, selvagens ou cultivadas. Altos níveis de DHA (16 a 31\%) foram encontrados em todos os membros da família analisados, exceto em C. grandocule, independentemente de seu habitat ou origem. As espécies analisadas do grupo Jordani (C. estor, C. promelas e C. humboldtianum) apresentaram altos níveis de DHA e EPA baixos $(<0,5 \%)$, como relatado anteriormente para C. estor cultivado. O baixo nicho trófico desses aterinopsídeos e sua capacidade de acumulação de ácidos graxos são fatores que tornam essas espécies notáveis candidatas à aquicultura sustentável.

Palavras-chave: Atherinopsideo, Chirostoma, Menidia, Odontesthes, Omega-3.

\section{INTRODUCTION}

It is well known that long chain polyunsaturated fatty acids (LC-PUFA) ( $\geq$ C20) have a critical importance in most aspects of human health (Calder, 2014, 2015; Lands, 2014, 2015; Liu et al., 2017), being arachidonic acid (ARA, 20:4n-6), eicosapentaenoic acid (EPA, 20:5n-3), and docosahexaenoic acid (DHA, 22:6n-3) the most important (Tacon, Metian, 2013; Cardoso et al., 2016). Among them, DHA is the least available in the western human diet (Stillwell, 2003).

Omega-3 LC-PUFA (EPA and DHA) come from various sources of wild caught fisheries and aquaculture. Those LC-PUFA are acquired and bioaccumulated from the food chain or, in the case of aquaculture through the formulated diets. Therefore, aquaculture is highly dependent on wild fisheries and thus competing with human demand, making it currently unsustainable (F.A.O., 2018).

In recent years, a high rate of biosynthesis and accumulation of DHA has been discovered in the pike silverside (Chirostoma estor Jordan, 1880) (Fonseca-Madrigal et al., 2012, 2014), a freshwater species from the neovolcanic plateau of Central Mexico that belongs to the Atherinopsidae family. This species together with C. promelas Jordan \& Snyder, 1899 and C. humboldtianum (Valenciennes, 1835) have an ancestral regional cultural value associated to human health (Martínez-Palacios et al., 2006). These species are nearly extinct due to habitat decay and overfishing driven by their cultural value and high local market prices ( $\$ 30-60$ US dollars $/ \mathrm{kg}$ ).

In particular, the pike silverside C. estor has been the most studied of the family in terms of fatty acid composition and/or metabolism, showing high proportion of DHA in flesh (31\% of total lipids), providing $15 \mathrm{mg}$ of DHA per gram of fillet, and 
concomitantly low levels of EPA (less than 0.5\%) (Martínez-Palacios et al., 2006). The mechanisms behind this proportion have been recently elucidated, finding two active DHA biosynthetic pathways: the Sprecher and a novel delta 4 pathway (FonsecaMadrigal et al., 2014; Oboh et al., 2017).

Studies on the South American pejerrey species Odontesthes bonariensis (Valenciennes, 1835), another member of this family, corroborated similar DHA levels (Gómez-Requeni et al., 2013; Bertucci et al., 2018). Therefore, considering the need for more sustainable aquaculture species and the fact that New World atherinopsids sit low in the trophic chain as secondary consumers (Martínez-Palacios et al. 2019), we aimed to analyze if other Neotropical Atherinopsid species captured from freshwater and brackish water environments, either wild or cultured, present a similar fatty acid profile.

\section{MATERIAL AND METHODS}

Fish sampling. Different species of atherinopsids were sampled, both from the natural environment and from farming systems of different regions. Within this family, the genus Chirostoma synonymous with Menidia (Miller et al., 2005), with species from the Mexican highlands, is divided into two large groups. The first, called Jordani, is composed of large fish, and in the second group, called Arge, is composed of small bait size fish, such as "charals" (Miller et al., 2005). All organisms were identified with dichotomous keys (Alvarez del Villar, 1970; Miller et al., 2005). Specifically, all species from Chirostoma genus were classified according to Miller et al. (2005) and Bloom et al. (2009). From the Jordani group, cultivated specimens (Freshwater/Cultured; FW/C) of C. estor and C. promelas were sampled from domesticated stocks held at Universidad Michoacana, Mexico. On the other hand, wild specimens (Freshwater/Wild; FW/W) of C. estor estor, C. estor copandaro and C. humboldtianum were sampled from the Mexican lakes of Pátzcuaro, Zirahúen and Zacapu, respectively. From the Arge group, wild brackish water (Brackish water/Wild; BW/W) Menidia beryllina (Cope, 1867) were caught in Sarasota Bay, Florida, USA and wild organisms (FW/W) were captured from Lake Pátzcuaro, Mexico: C. attenuatum (Meek, 1902) and C. grandocule (Steindachner, 1894). On the other hand, samples of freshwater cultivated (FW/C) O. bonariensis were obtained from stocks held at the Tokyo University of Marine Science and Technology, Japan. Brackish water cultivated (BW/C) O. bonariensis were obtained from INTECH facilities, Chascomus, and wild fish $(\mathrm{BW} / \mathrm{W})$ were captured in Trenque Lauquen, Argentina. Finally, wild (BW/W) and cage cultured (BW/C) O. hatcheri (Eigenmann, 1909) were obtained from the Ramos Mexía dam, Argentina. In all cases, 3-4 organisms were analyzed except C. grandocule, for which just one individual could be accurately identified.

Specimens of all species examined are deposited in well-recognized collections in Argentina, Japan, USA and Mexico with the following voucher numbers: Odontesthes bonariensis, Japan: MTUF 30753 (Museum of Marine Science, Tokyo University of Marine Science and Technology). Odontesthes bonariensis, Laguna Chascomús, Argentina: MACN 12422 (Museo Argentino de Ciencias Naturales, Buenos Aires). Odontesthes hatcheri, Embalse Ezequiel Ramos Mexía: MACN 10988. Menidia beryllina, Florida, U.S.A. AMNH 271361 (American Museum of Natural History, New York). 
Chirostoma promelas, Chapala, Mexico: CPUM 5028, Chirostoma attenuata, Lago de Pátzcuaro, Mexico: CPUM 7991, Chirostoma estor, Lago de Pátzcuaro, México: CPUM 7246, Chirostoma estor copandaro, Lago de Pátzcuaro, México: CPUM 2773, Chirostoma humboldtianum, Laguna de Zacapu, Mexico: CPUM 1007 and Chirostoma grandocule, Lago de Pátzcuaro, Mexico: CPUM 903 (Colección de peces, Universidad Michoacana de San Nicolás de Hidalgo, Michoacán).

Fatty acid analysis. Analysis of saturated, unsaturated, polyunsaturated fatty acids (PUFA) and long-chain polyunsaturated fatty acids (LC-PUFA) such as docosahexaenoic acid (DHA), eicosapentaenoic acid (EPA) and arachidonic acid (ARA), were carried out in all species. In the case of wild O. bonariensis, from Chasicó Lake (brackish water), Argentina, fatty acid values were taken from Kopprio et al. (2015).

Samples of all species were transferred on ice to the laboratory where they were subsequently frozen at $-80^{\circ} \mathrm{C}$ until processing. Samples from Japan and USA were freeze-dried after their collection and transferred to the laboratory where they were analyzed following the same analytical protocol than all the other species.

Fatty acid composition was analyzed from fish muscle as previously described by Fonseca-Madrigal et al. (2012). Lipid fraction of the different samples was extracted using chloroform:methanol $(2: 1, \mathrm{v} / \mathrm{v})$ containing $0.01 \%$ butylated hydroxytoluene (BHT). Fatty acid methyl esters (FAME) were prepared from extracted lipids by acid-catalyzed trans-esterification with $14 \%$ boron trifluoride in methanol at $90^{\circ} \mathrm{C}$ for $45 \mathrm{~min}$ and extracted using hexane. FAME were separated and quantified by gas chromatography with on-column injection using an Agilent Technologies GC 6850 equipped with a DB-23 silica column ( $30 \mathrm{~m}$ x, $0.25 \mu \mathrm{m} \times 0.25 \mathrm{~mm}$, Agilent), flame ionization detector with helium as gas carrier $\left(0.7 \mathrm{~cm}^{3} \mathrm{~min}^{-1}\right)$ and a temperature ramp $\left(110{ }^{\circ} \mathrm{C}-220{ }^{\circ} \mathrm{C}\right)$. Individual methyl esters were identified by comparison with known standards (SIGMA, ALDRICH) and by reference to published data.

After normality and homogeneity of variance were analyzed, a Student's t-test was applied between same species to find differences between individual fatty acids of wild and cultured fish (SIGMA PLOT 11.0).

\section{RESULTS}

All atherinopsid species analyzed contained between 24 and 37\% of saturated fatty acids. On the other hand, monounsaturated fatty acids levels between 12.8 and $27.5 \%$ were observed for O. bonariensis (wild freshwater) and C. grandocule, respectively. In all cases, oleic acid (18:1n-9) was the most abundant fatty acid contributing to monounsaturated fatty acids levels, which had higher amounts (at least two times, compared to the wild organisms) in all cultured species analyzed (Tab. 1).

The highest percentage (18\%) of total omega-6 PUFA was found in cultured C. promelas, C. estor estor and O. hatcheri, in contrast to the lower percentage (5\%) of wild/ freshwater O. bonariensis. It should be noted that in the case of cultured Chirostoma spp. and Odontesthes spp., the most abundant omega-6 PUFA was linoleic acid (18:2n-6), which is the precursor of omega-6 fatty acids family, including arachidonic acid (20: $4 n-6)($ Tab. 1). 
TABLE 1 I Composition and ratios of the most important fatty acids (percentage of total fatty acids by weight) of total lipid of flesh in members of the Atherinopsidae family: Chirostoma grandocule, C. attenuata, C. estor, C. promelas, C. humboldtianum, Menidia beryllina, Odontesthes bonariensis and 0 . hatcheri.

\begin{tabular}{|c|c|c|c|c|c|c|c|}
\hline $\begin{array}{l}\text { Fatty acid } \\
\text { composition } \\
(\% \pm \text { S.D.) }\end{array}$ & $\begin{array}{l}\text { C. promelas } \\
(F W / C)\end{array}$ & $\begin{array}{c}\text { C. estor estor } \\
(F W / C)\end{array}$ & $\begin{array}{c}\text { C. estor estor } \\
(F W / W)\end{array}$ & $\begin{array}{l}\text { C. estor } \\
\text { copandaro } \\
(F W / W)\end{array}$ & $\begin{array}{c}\text { C. } \\
\begin{array}{c}\text { humboldtianum } \\
(F W / W)\end{array}\end{array}$ & $\begin{array}{c}\text { M. beryllina } \\
(M W / W)\end{array}$ & $\begin{array}{l}\text { C. attenuata } \\
(F W / W)\end{array}$ \\
\hline Total saturated & $37.88 \pm 1.76$ & $35.89 \pm 7.23$ & $31.32 \pm 0.71$ & $33.69 \pm 0.69$ & $37.02 \pm 1.22$ & $36.99 \pm 0.60$ & $33.13 \pm 0.72$ \\
\hline $18: 1 n-9$ & $16.74 \pm 1.88$ & $17.01^{*} \pm 9.57$ & $6.38 \pm 1.26$ & $6.36 \pm 0.28$ & $9.11 \pm 1.08$ & $11.62 \pm 0.13$ & $10.06 \pm 0.44$ \\
\hline Total monoenes & $22.33 \pm 1.57$ & $20.90 \pm 11.3$ & $16.17 \pm 3.09$ & $15.05 \pm 0.37$ & $16.78 \pm 1.69$ & $24.97 \pm 0.34$ & $20.33 \pm 1.99$ \\
\hline $18: 2 n-6$ & $11.32 \pm 0.24$ & $0.28 \pm 0.5$ & $1.46^{*} \pm 0.69$ & $1.98 \pm 0.13$ & $2.07 \pm 0.42$ & $5.57 \pm 1.61$ & $3.62 \pm 0.19$ \\
\hline $20: 4 n-6$ & $0.16 \pm 0.03$ & $1.03^{*} \pm 0.3$ & $0.52 \pm 0.11$ & $0.17 \pm 0.02$ & $0.53 \pm 0.09$ & $4.23 \pm 1.27$ & $6.18 \pm 0.74$ \\
\hline Total n-6 PUFA & $18.36 \pm 1.22$ & $18.30 \pm 4.97$ & $14.71 \pm 0.90$ & $12.84 \pm 0.24$ & $9.64 \pm 0.46$ & $10.49 \pm 0.23$ & $11.67 \pm 0.99$ \\
\hline $18: 3 n-3$ & $0.52 \pm 0.02$ & $0.96 \pm 0.67$ & $2.36^{*} \pm 0.51$ & $0.73 \pm 0.36$ & $1.11 \pm 0.30$ & $1.58 \pm 0.23$ & $5.38 \pm 0.46$ \\
\hline EPA (20:5n-3) & $0.17 \pm 0.00$ & $0.45 \pm 0.78$ & $0.26 \pm 0.05$ & $0.24 \pm 0.02$ & $0.22 \pm 0.05$ & $5.44 \pm 0.55$ & $4.54 \pm 0.84$ \\
\hline DHA (22:6n-3) & $17.80 \pm 2.31$ & $21.61 \pm 2.75$ & $30.95^{*} \pm 5.56$ & $24.48 \pm 1.77$ & $21.33 \pm 1.69$ & $16.04 \pm 0.75$ & $19.53 \pm 2.76$ \\
\hline Total n-3 PUFA & $21.43 \pm 2.34$ & $25.09 \pm 3.12$ & $42.41^{*} \pm 7.17$ & $38.42 \pm 0.79$ & $36.55 \pm 3.03$ & $27.54 \pm 0.20$ & $34.87 \pm 0.37$ \\
\hline Total PUFA & $39.79 \pm 11.9$ & $43.38 \pm 13.3$ & $52.33 \pm 2.66$ & $51.27 \pm 1.02$ & $46.20 \pm 2.57$ & $38.04 \pm 0.31$ & $46.54 \pm 1.36$ \\
\hline DHA/EPA & 108 & 48 & 118 & 102 & 96 & 3 & 4 \\
\hline$n-3 / n-6$ & 1 & 1 & 3 & 3 & 4 & 3 & 3 \\
\hline $\begin{array}{l}\text { Fatty acid } \\
\text { composition } \\
(\% \pm \text { S.D. })\end{array}$ & $\begin{array}{l}\text { C. grandocule } \\
(F W / W)\end{array}$ & $\begin{array}{l}\text { O. bonariensis } \\
(F W / C)\end{array}$ & $\begin{array}{l}\text { O. bonariensis } \\
(F W / W)^{+}\end{array}$ & $\begin{array}{l}\text { O. bonariensis } \\
(B W / C)\end{array}$ & $\begin{array}{l}\text { O. bonariensis } \\
(B W / W)\end{array}$ & $\begin{array}{l}\text { O. hatcheri } \\
(B W / C)\end{array}$ & $\begin{array}{l}\text { O. hatcheri } \\
(B W / W)\end{array}$ \\
\hline Total saturated & 30.01 & $26.84 \pm 3.60$ & 31.50 & $26.62 \pm 1.60$ & $31.86 \pm 1.68$ & $23.95 \pm 0.95$ & $27.25 \pm 0.63$ \\
\hline $18: 1 n-9$ & 10.82 & $19.25^{*} \pm 4.77$ & $4.80 \pm 1.10$ & $17.27 \pm 6.09$ & $12.88 \pm 1.84$ & $16.59 * \pm 0.90$ & $8.64 \pm 0.93$ \\
\hline Total monoenes & 27.49 & $24.86 \pm 3.05$ & 12.80 & $25.56 \pm 3.03$ & $21.58 \pm 3.17$ & $24.19 \pm 1.88$ & $18.51 \pm 2.36$ \\
\hline $18: 2 n-6$ & 4.31 & $6.52 \pm 1.46$ & $1.80 \pm 0.80$ & $6.36^{*} \pm 1.16$ & $2.41 \pm 0.19$ & $15.82^{*} \pm 1.97$ & $4.99 \pm 0.31$ \\
\hline $20: 4 n-6$ & 5.05 & $2.07 \pm 0.59$ & $3.20 \pm 1.20$ & $3.27 \pm 0.35$ & $2.78 \pm 0.63$ & $1.27 \pm 0.11$ & $5.24^{*} \pm 0.41$ \\
\hline Total n-6 PUFA & 11.52 & $10.53 \pm 1.55$ & 5.00 & $10.09 * \pm 1.35$ & $5.56 \pm 0.88$ & $18.44^{*} \pm 1.83$ & $11.05 \pm 0.56$ \\
\hline $18: 3 n-3$ & 8.89 & $9.56 \pm 4.31$ & $1.20 \pm 0.60$ & $0.53 \pm 0.12$ & $1.78^{*} \pm 0.37$ & $1.67 \pm 0.20$ & $3.61^{*} \pm 0.48$ \\
\hline EPA (20:5n-3) & 4.15 & $3.17 \pm 0.58$ & $4.40 \pm 1.50$ & $3.23 \pm 1.02$ & $3.57 \pm 0.59$ & $1.61 \pm 0.25$ & $6.85^{*} \pm 0.67$ \\
\hline DHA (22:6n-3) & 12.47 & $20.12 \pm 4.37$ & $26.80 \pm 3.40$ & $24.90 \pm 2.45$ & $19.32 \pm 1.23$ & $23.44^{*} \pm 2.67$ & $18.88 \pm 1.97$ \\
\hline Total n-3 PUFA & 30.97 & $37.77 \pm 2.32$ & 33.70 & $28.85 \pm 5.52$ & $27.77 \pm 2.46$ & $28.38 \pm 2.28$ & $30.46 \pm 1.28$ \\
\hline Total PUFA & 42.50 & $37.77 \pm 5.43$ & 38.70 & $43.62 * \pm 1.50$ & $39.76 \pm 0.62$ & $49.56 \pm 1.96$ & $50.52 \pm 0.58$ \\
\hline DHA/EPA & 3 & 6 & 6 & 8 & 5 & 15 & 3 \\
\hline$n-3 / n-6$ & 3 & 4 & 7 & 3 & 4 & 2 & 3 \\
\hline
\end{tabular}

Freshwater (FW), Brackish water (BW), Wild (W), Cultured (C). Results are given as mean \pm SD ( $\mathrm{n}=3$ ). PUFA, polyunsaturated fatty acids. Eicosapentaenoic acid (EPA). Docosahexaenoic acid (DHA). ${ }^{*}$ Indicate statistical differences $(\mathrm{p}<0.05)$. Student's t-test was applied between same species to find differences between wild and cultured fish. +data published by Kopprio et al., 2015. 
Regarding total omega-3 PUFAs, concentrations ranging from 21 to $42 \%$ were observed. It should be noted that linolenic acid (18:3n-3) was found in high percentages in wild Chirostoma spp., compared to the cultured specimens. The same pattern was found in brackish water wild $O$. bonariensis, where cultured specimens were significantly lower. Freshwater O. bonariensis, together with charals C. attenuata and C. grandocule, presented the higher percentages of linolenic acid of all other analyzed species (Tab. 1).

Interestingly, all studied species presented a low content of eicosapentaenoic acid (EPA) (<7\%). Wild and cultured C. estor estor, C. estor copandaro, C. promelas, and C. humboldtianum (Jordani group) accumulated levels lower than $0.5 \%$, while the rest of the species (M. beryllina, C. attenuata, C. grandocule, O. bonariensis and O. hatcheri) presented from 1.7 to 6.9 percentages.

The most important feature found in the studied atherinopsids was their high flesh docosahexaenoic acid (DHA) content (12.5-31\% of total fatty acids). In general, wild specimens presented higher DHA levels than cultured ones, having C. estor estor the highest levels.

In all cases, the percentage of total PUFA was between $38 \%$ and $52 \%$ being omega-3 PUFA more abundant than omega-6 (n-3/n-6) (Tab. 1).

\section{DISCUSSION}

It is well known that in general, freshwater fish have a greater ability to biosynthesize LC-PUFA, such as DHA, than marine species. However, not all freshwater species studied to date accumulate abundant amounts of these fatty acids, as it depends on their environment, feeding habits and their de novo biosynthesizing capacities (Sargent et al., 2003).

A comparison of commercial fish species known to be a good source of omega-3 LC-PUFA have shown to contain high DHA levels ranging from 15 to 40\% (Tab.2; Mohanty et al., 2016). Interestingly, these species are mostly marine carnivores, and thus can bio accumulate DHA directly from the food chain, independently of their biosynthesis capacity. On the other hand, C. estor a freshwater fish can accumulate similar levels of DHA directly by biosynthetic activity (Fonseca-Madrigal et al., 2012). In this work we further explore other commercially important atherinopsid species to find out if they share similar fatty acid profile. In fact, high levels of DHA (16 to $31 \%$ ) were found in seven of the eight analyzed members of the family, independently of their habitat or origin. However, only the Jordani group (C. estor, C. promelas and C. humboldtianum) maintained the previously reported high levels of DHA with a concomitant low EPA levels $(<0.5 \%)$, providing these species with a distinctive fatty acid profile (Tabs. 1-2).

Differences between captive and wild fish fatty acid profiles were found. Linolenic acid levels (18:3n-3) in cultured C. estor were lower than in wild fish, while the opposite was found in O. bonariensis, which had lower values in wild than in cultured fish. These contrasting findings could be explained by several factors: 1) The dietary contribution of linolenic acid by the inclusion of vegetable oils in cultured fish;2) Differences in salinity of the environment; wild pejerrey were sampled from brackish water, which could promote DHA biosynthesis activity from linolenic acid as shown in C. estor 
(Fonseca-Madrigal et al., 2012), in contrast to cultured pejerrey in freshwater (Kopprio et al., 2015); 3) Different metabolic capacities between species to transform linolenic acid to DHA. Further studies are required to confirm the potential contribution of these or other factors.

Oleic (18:1n-9) and linoleic (18:2n-6) fatty acids levels are higher in cultured than in wild fish, which could be reflecting the fatty acid content of the offered feeds, as observed in other fish species (Bell et al., 2003; Tocher, 2003). All species with the exception of charals (C. attenuata and C. grandocule) and cultured pejerrey O. bonariensis (FW/C), have low linolenic acid levels $(<3.6 \%)$, suggesting that this fatty acid is being utilized as the precursor for de novo DHA biosynthetic pathway, as already described for C. estor (Fonseca-Madrigal et al., 2012). The high levels of linolenic acid found in $O$. bonariensis (FW/C) are probably due to their formulated diet.

Currently, aquaculture provides more than half of the total production of fish and seafood worldwide (F.A.O., 2018). However, fish culture is based mainly on the production of carnivore fish species (salmon, trout, tuna, etc.), which are on the top of the food chain and greatly depend on fisheries to provide fish oil and fishmeal as ingredients for their diets (Tacon, Metian, 2013), making it unsustainable in the foreseeable future. Efforts are currently being made to reduce costs and environmental impact by replacing marine fish sources with vegetable products. However, this strategy has led to a reduction of omega-3 levels in some aquaculture species (Shepherd et al., 2017; Sprague et al., 2017), thus reducing their nutritional value. Other species with low requirements of fishmeal and fish oil are also produced (such as tilapia and carp), however they do not contain high omega-3 concentrations, unless they are supplied in their diet, increasing production costs and reducing profitability.

For these reasons, FAO and several authors have recognized the need of selecting new aquaculture candidate species with more sustainable characteristics, such as low trophic level species, which translate in lower requirement of fishmeal and fish oil. In this respect, all species analyzed in this study are secondary consumers with filter-

TABLE 2 I Long Chain Polyunsaturated Fatty Acids (LC-PUFA) content in the muscle of common fish species and supplements for human consumption. Freshwater (FW), Wild (W).

\begin{tabular}{|c|c|c|c|c|c|c|}
\hline Species & Common name & EPA (\%) & DHA (\%) & $\begin{array}{l}\text { DHA/ } \\
\text { EPA }\end{array}$ & $\begin{array}{c}\text { EPA+ } \\
\text { DHA }\end{array}$ & References \\
\hline Salmo salar & Farmed salmon & 7.1 & 15.7 & 2.2 & 22.8 & Nichols (2007) \\
\hline Tuna & Tuna & 6.0 & 22.0 & 3.7 & 28.0 & Nichols (2007) \\
\hline Cod Liver oil & Cod Liver oil capsules & 8.8 & 11.0 & 1.3 & 19.8 & Nichols (2007) \\
\hline Jack mackerel & Mackerel & 10.9 & 11.5 & 1.1 & 22.4 & Nichols (2007) \\
\hline Farmed tilapia (Oreochromis niloticus) & Tilapia & 1.0 & 4.0 & 4.0 & 5.0 & Karapanagiotidis et al. (2006) \\
\hline Wild tilapia (Oreochromis niloticus) & Tilapia & 2.0 & 10.0 & 5.0 & 12.0 & Karapanagiotidis et al. (2006) \\
\hline Solea senegalensis & Senegalese sole & 6.0 & 29.5 & 5.0 & 35.5 & Norambuena et al. (2012) \\
\hline Cyprinus carpio & Carp & 0.4 & 0.3 & 0.8 & 0.7 & Jabeen, Chaudhry, (2011) \\
\hline Engraulis encrasicholus & Anchovy & 6.3 & 26.8 & 4.3 & 33.1 & Roncarati et al. (2012) \\
\hline Sparus aurata & Gilthead sea bream & 5.0 & 11.0 & 2.2 & 16.0 & Yildiz et al. (2008) \\
\hline Dicentrarchus labrax & Sea bass & 5.0 & 11.4 & 1.8 & 16.4 & Yildiz et al. (2008) \\
\hline Sardina pilchardus & Sardine & 13.6 & 14.8 & 1.1 & 28.4 & Bandarra et al. (2018) \\
\hline Chirostoma estor estor $\mathrm{FW} / \mathrm{W}$ & Pike silverside & 0.3 & 31.0 & 118.2 & 31.2 & This study \\
\hline
\end{tabular}


feeding characteristics and therefore low in the food chain (Horn et al., 2006; Ross et al., 2006; Martínez-Palacios et al., 2019). Thus, future large-scale production of some of these species may provide more sustainable alternative sources of DHA. This could also have the added benefit of avoiding pollutants normally acquired via bioaccumulation commonly present in marine fishmeal and fish oil (Tacon, Metian, 2013). Furthermore, regional and economical importance of atherinopsids together with their potential nutraceutical properties (i.e. salmon; Hasler, 2002) make them adequate species for aquaculture.

\section{ACKNOWLEDGMENTS}

To CONACYT trough the project "Laboratorio Nacional de Nutrigenómica y Microbiómica Digestiva Animal” (Grant 299055) and Biol. Jesús López-García for technical assistance. M.C. Xavier Madrigal-Guridi from CPUM-UMSNH fish collection. Dr. Gustavo Somoza from IIB-INTECH (CONICET-UNSAM), Argentina, and Dr. Rodolfo Cárdenas Reygadas from FES Iztacala (UNAM) for donating biological samples. Dr. Nate Brenan from MOTE Marine Lab, Sarasota, FL, USA for technical assistance in Cope 1867 Menidia beryllina sampling.

\section{REFERENCES}

- Alvarez del Villar J. Peces mexicanos; claves; 1970.

- Bandarra NM, Marçalo A, Cordeiro AR, Pousão-Ferreira P. Sardine (Sardina pilchardus) lipid composition: Does it change after one year in captivity?. Food chem. 2018; 244:408-13. https://doi. org/10.1016/j.foodchem.2017.09.147

- Bell JG, Tocher DR, Henderson RJ, Dick JR, Crampton VO. Altered fatty acid compositions in Atlantic salmon (Salmo salar) fed diets containing linseed and rapeseed oils can be partially restored by a subsequent fish oil finishing diet. J Nutr. 2003; 133(9):2793-801. https://doi. org/10.1093/jn/133.9.2793

- Bertucci JI, Tovar MO, Unniappan S, Navarro JC, Canosa LF. Effects of dietary sunflower oil on growth parameters, fatty acid profiles and expression of genes regulating growth and metabolism in the pejerrey (Odontesthes bonariensis) fry. Aquac Nutr. 2018; 24(2):748-57. https://doi. org/10.1111/anu.12603
- Bloom DD, Piller KR, Lyons J, MercadoSilva N, Medina-Nava M. Systematics and biogeography of the silverside tribe Menidiini (Teleostomi: Atherinopsidae) based on the mitochondrial ND2 gene. Copeia 2009; 2:408-17. https://doi. org/10.1643/CI-07-151

- Calder PC. Marine omega-3 fatty acids and inflammatory processes: effects, mechanisms and clinical relevance. Biochim Biophys Acta (BBA)-Mol Cell Biol L. 2015; 1851(4):469-84. https://doi. org/10.1016/j.bbalip.2014.08.010

- Calder PC. Very long chain omega-3 (n-3) fatty acids and human health. Eur J Lipid Sci Technol. 2014; 116(10):1280-1300. http://doi.org/10.1002/ejlt.201400025.

- Cardoso C, Afonso C, Bandarra NM. Seafood lipids and cardiovascular health. Nutrire. 2016; 41:7. https://doi.org/10.1186/ s41110-016-0008-8

- F.A.O. State of world fisheries and aquaculture. 2018. 
- Fonseca-Madrigal J, Navarro JC, Hontoria F, Tocher DR, MartínezPalacios CA, Monroig Ó. Diversification of substrate specificities in teleostei Fads2: characterization of $\Delta 4$ and $\Delta 6 \Delta 5$ desaturases of Chirostoma estor. J Lipid Res. 2014; 55(7):1408-19. https://doi. org/10.1194/jlr.M049791

- Fonseca-Madrigal J, Pineda-Delgado D, Martínez-Palacios C, Rodriguez C, Tocher DR. Effect of salinity on the biosynthesis of n-3 long-chain polyunsaturated fatty acids in silverside Chirostoma estor. Fish Physiol Biochem. 2012; 38(4):1047-57 https://doi.org/10.1007/ s10695-011-9589-6

- Gómez-Requeni P, Bedolla-Cázares F, Montecchia C, Zorrilla J, Villian M, Toledo-Cuevas EM et al. Effects of increasing the dietary lipid levels on the growth performance, body composition and digestive enzyme activities of the teleost pejerrey (Odontesthes bonariensis). Aquaculture. 2013; 416:15-22. https://doi. org/10.1016/j.aquaculture.2013.08.027

- Hasler CM. Functional foods: benefits, concerns and challenges-a position paper from the American Council on Science and Health. J Nutr. 2002; 132(12): 3772-81. https://doi.org/10.1093/jn/132.12.3772

- Horn MH, Gawlicka AK, German DP, Logothetis EA, Cavanagh JW, Boyle KS. Structure and function of the stomachless digestive system in three related species of New World silverside fishes (Atherinopsidae) representing herbivory, omnivory, and carnivory. Mar Biol. 2006; 149:1237-45 https://doi.org/10.1007/s00227006-0281-9

- Jabeen F, Chaudhry AS. Chemical compositions and fatty acid profiles of three freshwater fish species. Food Chem. 2011; 125(3):991-96. https://doi. org/10.1016/j.foodchem.2010.09.103

- Karapanagiotidis IT, Bell MV, Little DC, Yakupitiyage A, Rakshit SK. Polyunsaturated fatty acid content of wild and farmed tilapias in Thailand: effect of aquaculture practices and implications for human nutrition. J Agr Food Chem. 2006; 54(12):4304-10. https://doi.org/10.1021/ jf0581877
- Kopprio GA, Graeve M, Kattner G, Lara RJ. Fatty acid composition of wild Odontesthes bonariensis (Valenciennes 1835) larvae: implications on lipid metabolism and trophic relationships. J Appl Ichthyol. 2015; 31(4):752-55. https:// doi.org/10.1111/jai.12786

- Lands B. Historical perspectives on the impact of n-3 and n-6 nutrients on health. Prog Lipid Res. 2014; 55:17-29. https://doi. org/10.1016/j.plipres.2014.04.002

- Lands B. Omega-3 PUFAs lower the propensity for arachidonic acid cascade overreactions. BioMed Res Int. 2015:1-8. https://doi.org/10.1155/2015/285135

- Liu J, Cui Y, Li L, Wu L, Hanlon A, Pinto-Martin J, Raine A, Hibbeln JR. The mediating role of sleep in the fish consumption - cognitive functioning relationship: a cohort study. Sci Rep. 2017; 7:17961. https://doi.org/10.1038/s41598-01717520-w

- Martínez-Palacios CA, Racotta IS, RíosDurán MG, Palacios E, Toledo-Cuevas M, Ross, LG. Advances in applied research for the culture of Mexican silversides (Chirostoma, Atherinopsidae). Biocell, 2006; 30(1):137-48.

- Martínez-Palacios CA, Aguilar-Valdez MC, Strüssmann CA, Ríos-Durán MG, Toledo-Cuevas EM, Navarrete-Ramírez $\mathbf{P}$ et al. The orobranchial structures in four neotropical silversides (Teleostei: Atherinopsidae) related with feeding habits. Zoomorphology. 2019; 138(4):51123. https://doi.org/10.1007/s00435-01900457-1

- Miller RR, Minckley WL, Norris SM. Freshwater fishes of México. Illinois: The University of Chicago Press; 2005.

- Mohanty BP, Ganguly S, Mahanty A, Sankar TV, Anandan R, Chakraborty K, Paul BN, Sarma D, Syama Dayal J, Venkateshwarlu G, Mathew S, Asha KK, Karunakaran D, Mitra T, Chanda S, Shahi N, Das P, Das P, Akhtar MS, Vijayagopal P, Sridhar N. DHA and EPA content and fatty acid profile of 39 food fishes from India. Biomed Res Int. 2016; 4027-437. https://doi. org/10.1155/2016/4027437

- Nichols PD. Fish oil sources. In: Brevik H, editor. Long-chain omega-3 specialty oils. Bridgwater (England): Oily Press; 2007. p.23-42. 
- Norambuena F, Estevez A, Bell G, Carazo I, Duncan N. Proximate and fatty acid compositions in muscle, liver and gonads of wild versus cultured broodstock of Senegalese sole (Solea senegalensis). Aquaculture. 2012; 356:176-85. https://doi. org/10.1016/j.aquaculture.2012.05.018

- Oboh A, Kabeya N, Carmona-Antoñanzas G, Castro LFC, Dick JR, Tocher DR, Monroig O. Two alternative pathways for docosahexaenoic acid (DHA, 22:6n-3) biosynthesis are widespread among teleost fish. Sci Rep. 2017; 7(1):3889. https://doi. org/10.1038/s41598-017-04288-2

- Roncarati A, Brambilla G, Meluzzi A, Iamiceli AL, Fanelli R, Moret I, Ubaldi A, Miniero R, Sirri F, Melotti P, di Domenico A. Fatty acid profile and proximate composition of fillets from Engraulis encrasicholus, Mullus barbatus, Merluccius merluccius and Sarda sarda caught in Tyrrhenian, Adriatic and Ionian seas. J Appl Ichthyol. 2012; 28(4):545-52. https://doi.org/10.1111/j.14390426.2012.01948.x

- Ross LG, Martínez-Palacios CA, Aguilar Valdez MC, Beveridge MCM, ChavezSanchez MC. Determination of feeding mode in fishes: the importance of using structural and functional feeding studies in conjunction with gut analysis in a selective zooplanktivore Chirostoma estor estor Jordan 1880. J Fish Biol. 2006; 68(6):1782-94. https://doi.org/10.1111/ j.1095-8649.2006.01061.x

- Sargent JR, Tocher DR, Bell JG. The lipids. In: Halver JE, Hardy RW, editors. Fish Nutrition. 3th ed. San Diego: Elsevier; 2003. p.181-257.
- Shepherd CJ, Monroig O, Tocher DR. Future availability of raw materials for salmon feeds and supply chain implications: The case of Scottish farmed salmon. Aquaculture. 2017; 467:49-62. https://doi.org/10.1016/j. aquaculture.2016.08.021

- Sprague M, Betancor MB, Dick JR, Tocher DR. Nutritional evaluation of seafood, with respect to long-chain omega-3 fatty acids, available to UK consumers. P Nutr Soc. 2017; 76 (OCE2): E38. https://doi. org/10.1017/S0029665117000945

- Stillwell W, Wassall SR. Docosahexaenoic acid: membrane properties of a unique fatty acid. Chem phys lipids. 2003; 126(1):1-27. https://doi.org/10.1016/S00093084(03)00101-4

- Tacon AG, Metian M. Fish matters: importance of aquatic foods in human nutrition and global food supply. Rev Fish Sci. 2013; 21: 22-38. https://doi.org/10.1080/ 10641262.2012.753405

- Tocher DR. Metabolism and functions of lipids and fatty acids in teleost fish. Rev Fish Sci. 2003; 11(2):107-84. https://doi. org/10.1080/713610925

- Yildiz M, Şener E, Timur M. Effects of differences in diet and seasonal changes on the fatty acid composition in fillets from farmed and wild sea bream (Sparus aurata L.) and sea bass (Dicentrarchus labrax L.). 2008; 43(5):853-58. Int J Food Sci Tech. https://doi.org/10.1111/j.13652621.2007.01526.x

\section{AUTHOR'S CONTRIBUTION 자}

Carlos Antonio Martínez-Palacios: Project administration, Resources, Supervision.

Sibila Concha-Santos: Investigation, Methodology.

Elva Mayra Toledo-Cuevas: Supervision, Writing-review \& editing.

María Gisela Rios-Durán: Investigation, Validation, Writing-original draft.

Carlos Cristian Martínez-Chaves: Conceptualization, Writing-original draft.

Pamela Navarrete-Ramírez: Conceptualization, Funding acquisition, Project administration, Supervision.

Luciana Raggi: Software, Visualization, Writing-review \& editing.

Carlos Strussmann: Data curation, Funding acquisition, Methodology, Resources.

Juan Pablo Hualde: Formal analysis, Investigation, Validation.

Mariela Ana Demicheli: Data curation, Formal analysis, Investigation, Resources.

Jorge Fonseca-Madrigal: Data curation, Formal analysis, Funding acquisition, Investigation,

Methodology, Resources, Supervision, Writing-original draft, Writing-review \& editing. 


\section{Neotropical |chthyology}

OPEN $\partial_{\text {ACCESS }}$

\section{(c) (1)}

This is an open access article under the terms of the Creative Commons Attribution License, which permit use, distribution and reproduction in any medium,

provided the oniginal work is properly cited.

Distributed under

Creative Commons CC-BY 4.0

๑) 2020 The Authors.

Diversity and Distributions Published by SB

Official Journal of the

Sociedade Brasileira de Ictiologia

SBI

\section{ETHICAL STATEMENT}

Not applicable.

\section{COMPETING INTERESTS}

The authors declare no competing interests.

\section{HOW TO CITE THIS ARTICLE}

- Martínez-Palacios CA, Concha-Santos S, Toledo-Cuevas EM, Ríos-Durán MG, MartínezChávez CC, Navarrete-Ramírez P, Raggi L, Strussmann C, Hualde JP, Demicheli MA, Fonseca-Madrigal J. High levels of docosahexaenoic acid are present in eight New World silversides (Pisces: Atherinopsidae). Neotrop Ichthyol. 2020; 18(2):e190089. https://doi. org/10.1590/1982-0224-2019-0089 